Mathematical Modelling and Analysis

Volume 5, 2000, PAGeS 55-66

(C) 2000 Technika

\title{
CONCEPTUAL ARCHITECTURE FOR DYNAMIC DOMAIN REPRESENTATION
}

\section{DZEMYDIENE்}

Institute of Mathematics and Informatics

Akademijos 4, Vilnius 2600, Lithuania

E-mail: daledz@ktl.mii.lt

Received August 15, 1999

\begin{abstract}
This paper considers the representation of knowledge content of a dynamic application domain. The multi-layered conceptual architecture assembles the models of knowledge representation on a higher level including conceptual models of information structures, dynamic process analysis, and problem solving tasks. The model represents behavioural analysis of the target system based on a piecewise-linear aggregate approach.
\end{abstract}

Key words: Decision support system, conceptual model, knowledge representation techniques, piecewise linear aggregate approach

\section{INTRODUCTION}

The knowledge of rapidly changing environment may have many types and forms of representation, including description of individual objects, classes of objects with their semantic interrelationships, behavioural processes, descriptive definitions of domain-specific terms, criteria for decision making, etc. Some exceptional features of complex domains, especially dynamic components, require additional means for knowledge representation, data verification and assurance of efficiently making decision processes [4-7, 13].

The proposed multi-layered conceptual architecture assembles the models of knowledge representation on a higher level including conceptual models of information structures, dynamic process analysis and tasks.

The representational platform describes a general component model that is a basis for expressing properties of the problem domain. The representation of knowledge content should be expressed in a meaningful way in order to develop the decision support system. According to [1], the expressiveness 
of representation is related to the type of knowledge content that can be expressed.

Traditionally, three perspectives of the target system are dominant in conceptual system modelling: data perspective, process perspective and behaviour perspective. The process perspective most frequently means identification of the relevant operational or active components of the system and their interrelationships. The main activities in the target system are identified, including the information flows, event occurrences, state changes, etc.

The integration possibilities of two knowledge representation techniques (i.e., semantic model constructions for representing information structures and a piecewise-linear aggregate approach for functional analysis of processes) are considered. The results of applying the piecewise-linear aggregate approach were obtained under the guidance and advice of Prof. H. Pranevičius. The collaboration with the Department of Business Informatics at Kaunas University of Technology have also made a valuable contribution to the results mentioned in this paper. The attention of using integrated conceptual models is focused on the consideration of informational semantics and temporal aspects of the transportation domain.

\section{THE PROBLEMS OF DYNAMIC DOMAIN REPRESENTATION}

Dynamic application domains have significant dynamic components, i.e., that the conditions of the real system at the time a decision is made, are the results of analysis of the past history of the system, and influence its subsequent future behaviour.

The study of application domains such as environment protection, planning of tasks of an automated system, robot control, medical diagnosis and transport management, makes it possible to consider them as dynamically changing subject areas in which several features are essential for the analysis and representation:

- complexity of a structure of processes;

- multiple sub-systems with their own complex mechanisms interacting as internal or external parts;

- time and geographical dependency;

- a great volume of data acquired from the process;

- a large amount of measurement points at different time and the conditions causing the overlapping and conflict between different observations, and uncertainty of measurements and reports;

- multi-criteria decision making.

Temporal knowledge representation aspects are of primary interest in the decision-making context when the problems of retrospective analysis and prognosis are concerned $[8,15]$. For the prognosis of further evolution of the target area and the system behaviour it is important to design an adequate imitation model of the system. For these purpose the model represents behaviour of the 
target system, and is based on the piecewise-linear aggregate approach [14, 15] which allows to construct a compatible scheme of specifying the dynamic environment.

The integration possibilities of two knowledge representation techniques (i.e., semantic model constructions and piecewise-linear aggregates) are considered here. Such a combined model is illustrated by examples of the description of transport management system.

The management of transportation may be considered as a dynamically changing and complex technology in which several features are essential for the analysis:

- the cargo being carried by the same transport unit using several different transport kinds;

- a long conveyance cycle and international character of transportation;

- complex relationships between separate conveyance links;

- multiple subsystems with their own complex mechanisms interacting as internal or external parts;

- time and geographic dependencies in process relationships.

Decision making is performed considering a lot of various factors: evaluating the technical infrastructure of transportation and organizational aspects, comparing reports with the real situation.

The results of analysis of attractiveness of the alternative transportion modes between forwarding agents have shown that the most important evaluation criteria are: transport cost, reliability, and lead-time of transportation. The weight of these three factors is varying among different respondents. It is linked to the nature of cargo being carried and depends on special requirements of senders and so on [16, 17, 23].

\section{REPRESENTATION OF INFORMATION STRUCTURES BY COMPONENTS OF THE SEMANTIC MODEL}

A deep representation of knowledge provided by the semantic model allows an explicit representation of domain specificity.

A representation system can be viewed as modelling of concepts in several levels. One level of representation concerns with knowledge objects that are domain-related concepts (e.g., transportation type, speed limit, carrying capacity). This level embraces two different views of world knowledge: extensional view and intensional view. The higher level of representation corresponds to the epistemological level of semantic network representation (as introduced in [3] or described by meta-plane in [1]), where the knowledge objects are representational objects (e.g., symbol, entity, relation, value). Modelling objects by intentional and extensional aspects are fundamental in the information system design theory. The intensional features of data are 
closely related with their semantics. The extensional features of data play an important role in the stages of knowledge acquisition from databases.

The levels of knowledge in terms of meta-level and object knowledge are regarded to be relative in respect one another. The definitions of the extensional and intensional representation are described in [24] by the comprehension of a multi-layer logic. The multi-layer logic is an extended version of a first order logic that involves sets as its semantics. In [24] the intensional representation is defined as follows:

Let $X_{\text {ext }}$ denote the extension of a concept $X_{\text {con }}$ with respect to its extensionality, and $X_{\text {int }}$ denote the extension of a concept $X_{\text {con }}$ with respect to its intensionality. Then, the definition $\left(\forall x / X_{e x t}\right)\left(\exists p p / X *_{i n t}\right)(\forall p / p p) p(x)$ is the intentional representation of a concept $X_{\text {con }}$, where $X *_{i n t}$ is a powerset of $X_{\text {int }}$.

For example, $\left(\forall x / A N I M A L_{e x t}\right)\left(\exists p p / A N I M A L *_{\text {int }}\right)(\forall p / p p) p(x)$ is the intensional representation of concept $A N I M A L_{c o n}$. This means that the concept $A N I M A L$ is defined so that for every member $x$ of $A N I M A L_{e x t}$ there exists a subset $p p$ of $A N I M A L *_{i n t}$ such that $x$ satisfies all the members of $p p$.

The above definition agrees with the meaning of abstraction hierarchies of concepts. The interpretation of a subclass is based on the notion of a class as representing an intensional concept. The corresponding extensional term such as "category" is described in [21] by a collection (set) of individuals. The results of [20], SDM [3] made a basis for understanding and representing the generalization and specialization hierarchies. In the abstraction hierarchies $A N I M A L_{c o n}$ is a generalization of $B I R D_{c o n}$. The aggregation hierarchy was defined in terms of "part-of" relations, and an association hierarchy was defined in terms of the powerset relation in [24].

The structure of concepts ties the characteristics of each concept together. It is based on the relationship of intentional containment between concepts described in $[9,10]$.

Three types of abstractions of the relationship between chosen concepts are used in constructing a semantic model: generalization, decomposition (inverse relation is aggregation), and transformation.

Generalization abstraction defines the type of intention "concept-concept": $E_{j} I S \_A E_{i}$, where one concept is defined by the set of other concepts. According to [9] graphical notation of generalization abstraction is presented in fig. 1.

Aggregation (decomposition) abstraction helps us to construct a concept by other concepts depending on their decomposition or functional dependence: $E_{i} P A R T \_O F E_{j}$.

Transformation is very similar to that of the aggregation, except that it contains a calculation rule $F$, which specifies how the values representing the occurrences of the defined concept are derived from the values representing the defining concepts.

According to [9] graphical notation of aggregation and transformation ab- 


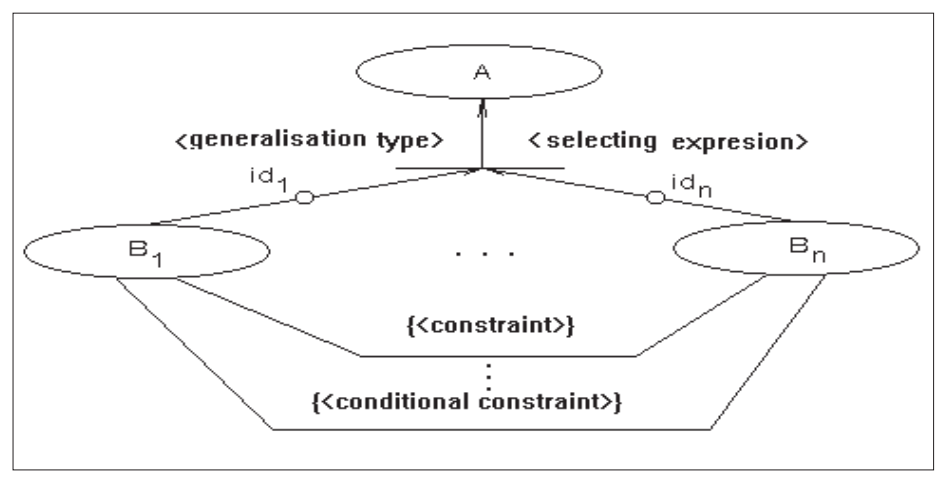

Figure 1. Generalization relationship.

stractions is presented in fig. 2 .

When describing the transportation management system, each level of the information system has to assure a certain operatively working layer of information.

The first level of information consists of data on the route network technical characteristics: lengths and technical state of routes, speed limits, limits of route permeability, etc.

The conceptual schemes of the topology of the road network are suggested using previously defined semantic constructions. The semantic model of route network technical characteristics is shown in fig. 3 .

When determining technical characteristics of the transportation management system we must represent freightage junction types, such as border crossing points, main cities, ports, etc. We will further describe these intersection points as junctions or nodes in the model.

Each junction - node is described by its type, identification and geographical location. The junction of multi-modal transport can to assure delivery of freight by certain means of reloading of freight into another means of transportation and its forwarding to another transport junction-node.

The structure that describes freightage junction technical characteristics is shown in fig. 4.

The evaluation and selection of route also depends on the type of loads and on the desirable duration of transportation. Information accumulated in the system should help determine the technical state and reliability of routes, and transportation duration. In order to select the optimal route of transportation, the price of transportation and reliability of the route play an important role as well.

Reliability of the route is a complex evaluation and it is not easily determined. It should reflect assurance of load safety, possibility of assault, assurance of freight delivery within the limits of the fixed terms. 


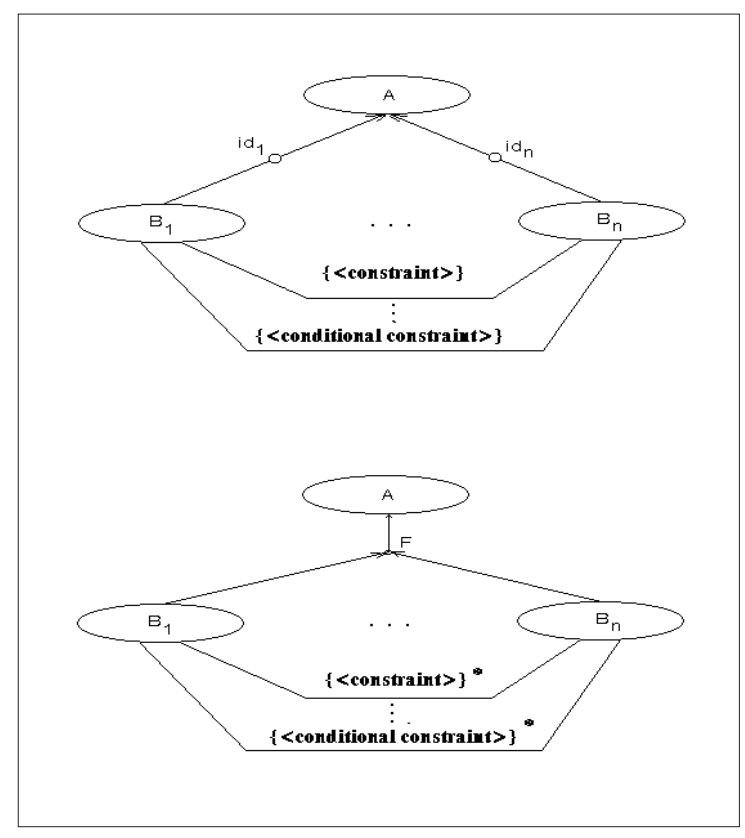

Figure 2. Graphical notation of aggregation and transformation relationships.

\section{REPRESENTATION OF FUNCTIONAL REQUIREMENTS}

A dynamic subject area has significant dynamic components. This dynamic characteristic of the target system may be represented explicitly in the formulation of a problem or implicitly by defining problem constraints. This dynamic aspect is possibly the major feature of dynamic domain problems and it is important to underline the role of simulation models in which these dynamic characteristics can be more easily and intuitively represented.

In many conceptual models the aspects of static and dynamic representation and communication between objects, their interaction with respect to time are now being considered (methodologies like BIER [11], REMORA [18], TEMPORA [22]). Some recent models [2, 12, 19] are integrated object-oriented concepts in conceptual design and reduce the complexity of design tasks by specifying object classes, inheritance links and actions in these classes. Different mathematical schemes are used for creating a formal description of dynamic systems, such as: data flow and state transition diagrams, temporal logic technique, Petri-net classes, and abstract communicating methods.

In this paper, we propose the aggregate approach according to $[14,15$, 16] for creating an imitation model which allows to represent processes of transportation management system and to analyze the functioning results of 


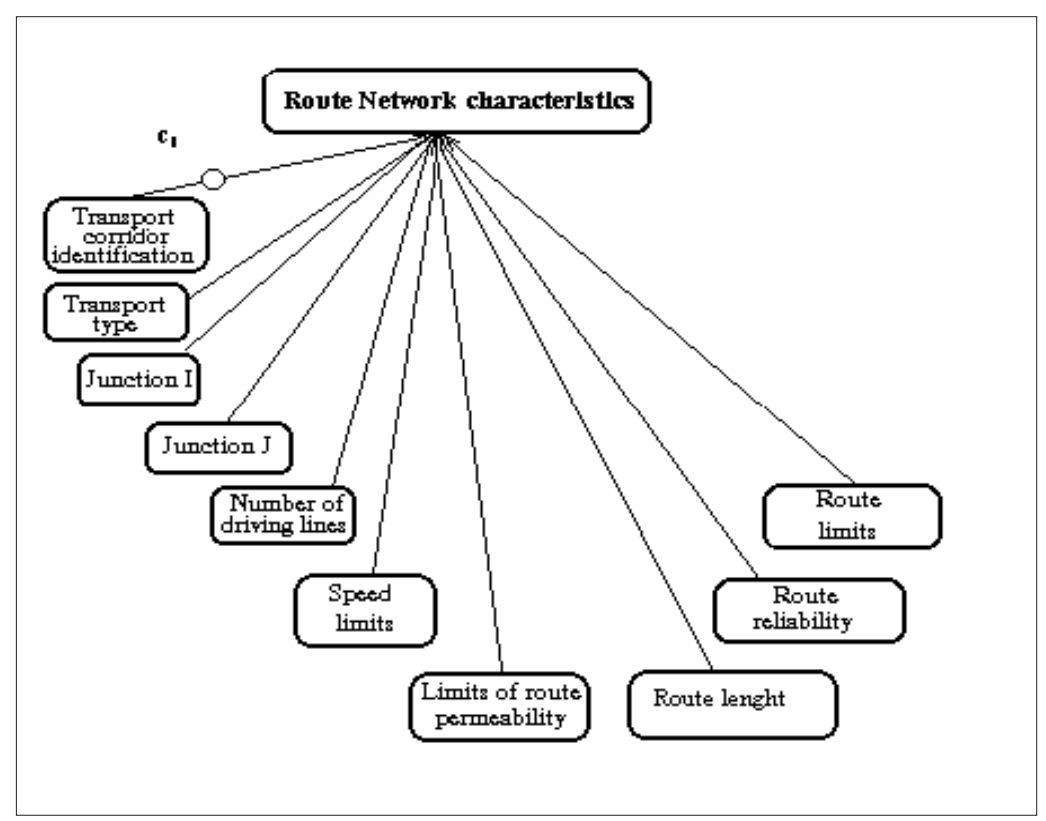

Figure 3. Conceptual scheme of road network characteristics.

such application domain.

The aggregate approach $[8,14-17]$ is used for functional representation of processes in the multi-modal transportation system.

The theoretical basis of the aggregate approach is a piecewise-linear aggregate (PLA) for formal specification of systems. Piecewise-linear aggregates belong to the class-time automaton. In the aggregate approach a system is represented as a set of PLA interacting in hierarchical manner.

The essence of PLA is that the state of an aggregate has a special structure consisting of two components:

- a discrete state component taking a countable set of values;

- a continuous component with co-ordinates.

The PLA is defined by a set of states $Z$, input signals $X$, and output signals $Y$. The state of an aggregate can change in two cases only: when an input signal arrives at the aggregate or when the continuous component acquires a definite value. The aggregate functioning is considered on the set of time moments $t \in T$. The state $z \in Z$ of a piecewise-linear aggregate is the same as the state of a piecewise-linear Markov process, i.e., $z(t)=\left(\nu(t), z_{\nu}(t)\right)$, where $\nu(t)$ is the discrete state component taking values in the countable set of values and $z_{\nu}(t)$ is the continuous state component comprised of $z_{\nu 1}(t), z_{\nu 2}(t), \ldots, z_{\nu k}(t)$ co-ordinates.

The model based on the piecewise-linear aggregate approach makes it possible to express the communication between informational objects of dynamic 


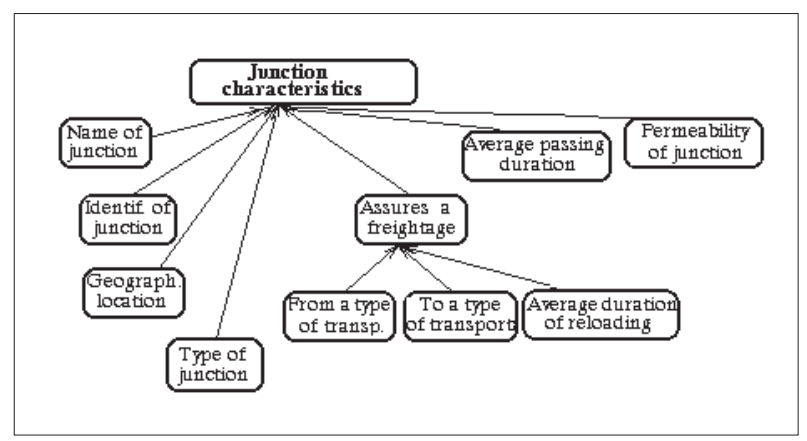

Figure 4. The conceptual scheme of multi-modal freightage junction characteristics.

environment. In this stage of requirement specification we can validate the semantic model of static data structures and specify the relations of usage of needed information structures.

According to $[8,16,17]$ the whole modeling system of transportation management was divided into three subsystems-aggregates: "Environment", "Node" and "Chain".

The conceptual structural scheme of PLA component application in the transportation management system is presented in fig. 5 .

The subsystem "Environment" is intended for modelling of the real environment of multi-modal transportation. It has two output channels with the first and the last junction-nodes of the "Node" subsystem, through which the "Environment" passes the output signal about the order to start goods transportation in the west-east or east-west direction, respectively.

The subsystem "Environment" has two incoming channels with the first and the last junction nodes of "Node" subsystem, through which the "Environment" gets the incoming signal about the completed transportation of certain goods.

The subsystem "Node" is intended for modelling the certain node of the transportation route, i.e., a port, a city, or a border crossing points. Each node in such a subsystem has out-going channels with the "Chain" subsystem, through which the "Node" passes the out-going signal about the finished goods transportation through the "Node" (goods loading, warehousing, customs). Also, each "Node" subsystem has incoming channels with the "Chain" subsystem to the right and to the left side (except the first and the last "Nodes" which have channels with the "Environment"). These channels are main through which the "Node" gets the incoming signal about the completeness of transportation of goods through the "Chain". The delays of transformation (i.e. time duration) are caused by waiting for a transport time schedule, stops for driver's relaxation, etc.

The subsystem "Chain" is designated for modelling a certain chain of the transportation route, i.e., a land-road, a sea-road, or a rail-road. When the 


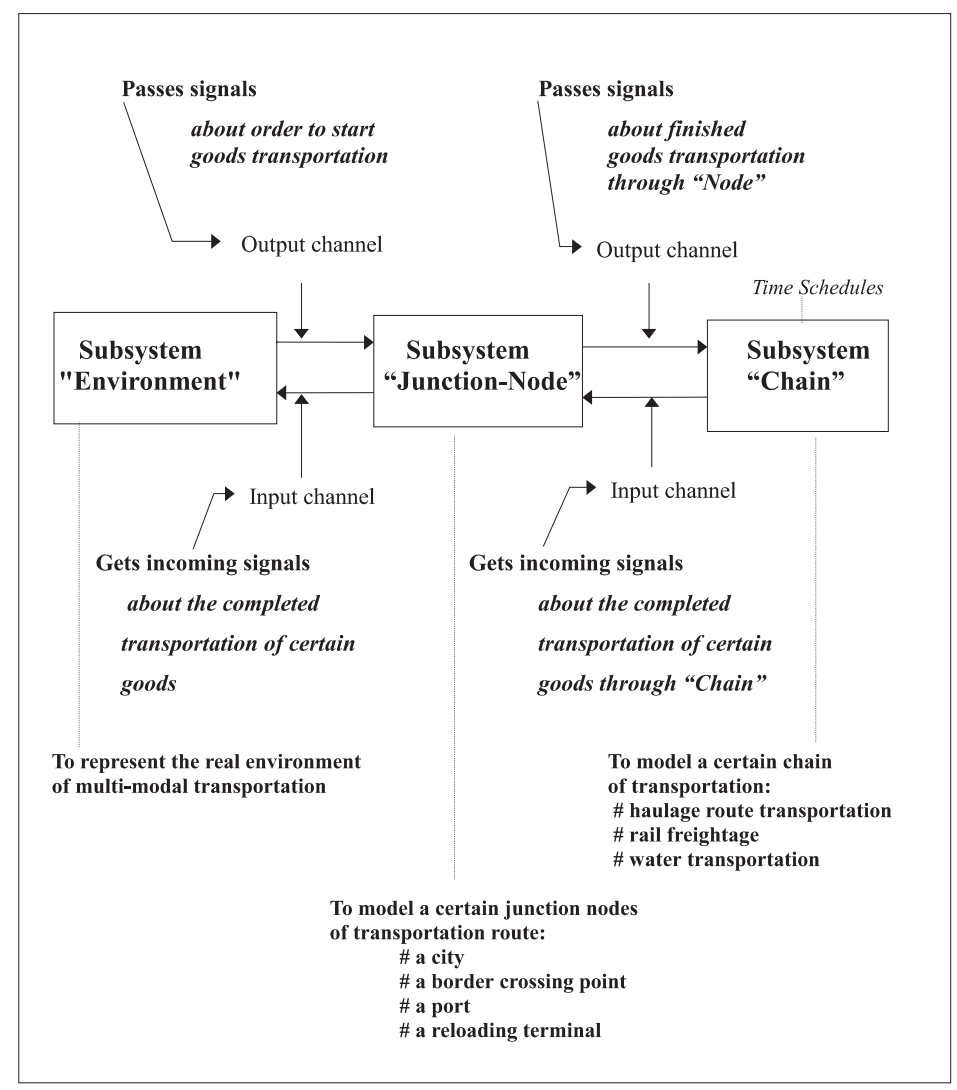

Figure 5. The structural scheme of using piecewise-linear aggregate components for multi-modal transportation representation.

goods arrive at the "Chain" they have to wait (or not) for the time schedules of the next transportation means.

The formal description of the aggregate is composed of certain constructions that are included in the description of aggregates "Node", "Chain" and "Environment". The main constructions are: the set of input signals, the set of output signals, the set of external events, the set of internal events, the controlling sequences, the aggregate states, the initial state of aggregate, and the description of operators of system behaviour.

The main modelling characteristics of the aggregate model are: certain route transportation time, price, and reliability. The reliability is a parameter which represents how long the goods can maximally be late with respect to the medium transportation time.

The following time characteristics are important here: $t_{i}$ is a time moment when the load arrives at the route; $\Delta t_{i}$ is a time interval during which the load is transported through the route; $t_{j}$ is a time moment when the load 
arrives at the junction-node system; $\Delta t_{j}$ is a time interval during which load was transported through the junction-node.

The information system accumulates information on all the needed parameters as well as average junction-node passing duration, permeability of junctions reloading, storage duration, etc. It is necessary here to evaluate type and group of the loads and freights. It is also necessary to know the desirable freight transportation duration and its reliability. Freights can differ in type, for example, ecologically dangerous, having non-standard measures, the ones requiring an especially high degree of safety, etc. The imitation of modelling helps to evaluate such parameters.

\section{CONCLUSIONS}

The approach for representing static and dynamic aspects of transportation management system and expressing them by means of knowledge representation has been considered in this paper.

The integration possibilities of two knowledge representation techniques (i.e., semantic model constructions and the model of piecewise-linear aggregates) are presented.

The proposed multi-layered conceptual architecture is comprised of the models of knowledge representation on a higher level including conceptual models of information structures, dynamic process analysis and tasks. The adequate imitation model of the behavioural analysis allows us to predict further evolution of the target system and to increase the quality of decision making.

\section{REFERENCES}

[1] A. Aamodt. A Knowledge-Intensive, Integrated Approach to Problem Solving and Sustained Learning. Knowledge Engineering and Image Processing Group. University of Trondheim, 1991.

[2] G. Booch. Object-oriented Analysis and Design. Redwood City, CA: Benjamin/Cummings, 1994.

[3] M. L. Brodie. Association: a Database Abstraction for Semantic Modelling. In: EntityRelationship Approach to Information Modeling and Analysis. P.P.Chen (Ed.), North - Holland, Amsterdam, 1983.

[4] J. Brunet, C. Cauvet and L. Lasoudris. Why Using Events in High-Level Specification. In: Entity-Relationship Approach: The Core of Conceptual Modelling. H. Kangassalo (Ed.) North-Holland, Amsterdam, 1991, 211 - 223.

[5] V. De Antonelis and B. Zonta. A Tool For Modeling Dynamics in Conceptual Design. In: A. Albano, V. De Antonelis, A. Di Leva (Eds.) Computer-Aided Database Design: the DATAID Project. North- Holland, Amsterdam , 1985, 17 - 31.

[6] D. Dzemydienè. Representation of Decision Making Processes for the Ecological Evaluation System. Annals of Operation Research. Baltzer Science Publishers. The Netherlands, 51 1994, 349 - 366.

[7] D. Dzemydienè and H. Pranevichius. Description of a Dynamically Changing Environment in a Decision Support System. In: Proc. of the Baltic Workshop on National 
Infrastructure Databases: Problems, Methods, Experiences, Vilnius, 1994, Vol. 2, 102 $-111$.

[8] D. Dzemydienè and H. Pranevičius. Integration of Aggregate Approach in Knowledge Representation of the Multi-modal Transport Evaluation System. In: Proc. of the Third International Baltic Workshop "Databases and Information systems", Riga, 1998, $139-151$.

[9] H. Kangassalo. On the Concept of Concept in Conceptual Schema. In: Proc of the First Scandinavian Research Seminar on Information Modelling and Data Base Management. H. Kangassalo (Ed.), Tampere, Ser.B Vol.17, 1982, 129 - 172.

[10] H. Kangassalo. On the Concept of Concept for Conceptual Modelling and Concept Detection. Information Modelling and Knowledge Bases III. S. Ohsuga, H. Kangassalo, H. Jaakkola, K. Hori, N. Yonezaki (Eds.). IOS Press, 1992, 17-58.

[11] G. Kappel and M. Schrefl. A Behaviuor Integrated Entity Relationship Approach for the Design of Object-Oriented Databases. In: Proc. of 7-th Int. Conf. on ER Approach. North-Holland C.Batani (Ed.), Amsterdam, 1989, 311 - 328.

[12] C. Larman. Applying UML and Patterns. An Introduction to Object-Oriented Analysis and Design. Prentice-Hall. Inc., 1998.

[13] P. Loucopoulos. Extending Database Design Techniques to Incorporate Enterprise Requirements Evolution. In: Proc. of the Baltic Workshop on National Infrastructure Databases: problems, methods, experiences, Vilnius, 1994, Vol. 2, 8 - 23.

[14] H. Pranevicius. Aggregate Approach for Specification, Validation, Simulation and Implementation of Computer Network Protocols. Lecture Notes in Computer Sciences. Springer-Verlag, 502 1991, 433 - 477.

[15] H. Pranevicius. Specification and Analysis of Real-Time Systems by Means of Aggregate Approach. In: Proc. of the 3rd Baltic Summer School on "Information technology and System Engineering", Kaunas. Technologija, 1995, $60-87$.

[16] H. Pranevičius and V. Pilkauskas. The Use of Aggregate Approach for Simulation of Multi-modal Transport System. In: Proc. of the International Workshop "Modelling and Simulation within a Maritime Environment", Riga, 1998.

[17] H. Pranevičius, R. Palšaitis, V. Pilkauskas, D. Dzemydienè, G. Vidžiūnaitè and G. Budnikas. The Modelling of Multimodal Transport System Development of Republic of Lithuania. The Manual Report No. 187. Kaunas University of Technology (in Lithuanian), 1996.

[18] C. Rolland. Event Driven Synchronisation in REMORA. In: Proc. of the Third Scandinavian Research Seminar on Information Modelling and Data Base Management. H. Kangassalo (Ed.) Ser B. Vol. 22, Tampere, 1984, 245-275.

[19] M. Schreft. Behaviour Modelling by Stepwise Refining Behaviour Diagrams. In: EntityRelationship Approach: the Core of Conceptual Modelling. H. Kangassalo (Ed.), NorthHolland , Amsterdam.1991, 119 - 134

[20] J.M. Smith and D.C.P. Smith. Database abstractions: Aggregation and generalization. ACM Transactions on Database Systems, 2 (2), 1977, 105 - 133.

[21] E. Smith and D. Medin. Categories and Concepts. Harvard University Press, 1981.

[22] TEMPORA. TEMPORA Esprit 2 Project. Concepts Manual, 1993.

[23] Transport Routes between Western Europe and Russia. VTT Communities and Infrastructure Transport Research. NEA Transport Research and Training. ESPOO, 1994.

[24] H. Yamauchi and S. Ohsuga. Modelling Objects by Extensions and Intensions - A Theoretical Background of KAUS. Information Modelling and Knowledge Bases III. S. Ohsuga, H. Kangassalo, H. Jaakkola, K.Hori, N.Yonezaki (Eds.). IOS Press, 1992, 160-173. 


\section{DINAMINĖS DALYKINĖS SRITIES ATVAIZDAVIMO KONCEPTUALI ARCHITEKTÜRA}

\section{DALE் DZEMYDIENE்}

Straipsnyje nagrinëjami dinamiškai kintančios dalykinès srities žinių atvaizdavimo klausimai. Informacinès struktūros semantinis modelis ir dalykinëje srityje vykstančiu procesuc imitacinis modelis apjungiami į bendrą konceptualią architektūrą, kurios pagalba atvaizduojami reikalavimai sprendimų priëmimo sistemai. Informacinès struktūros atvaizdavimo modelis konstruojamas, taikant tris sąryšiuc aprašymo abstrakcijų tipus (apibendrinimą, dekompoziciją ir transformaciją), kurie nusako ryšius tarp iškiriamų sąvokų. Imitacinio modelio sudarymas grindžiamas dalimis tiesiniu agregatų taikymo metodu, kurio pagrindinis privalumas yra galimybė išreikšti diskretines ir tolydines procesu veiklos charakteristikas ir gauti modeliuojamos veiklos rezultatus. 